JIKAP PGSD: Jurnal IImiah Illmu Kependidikan

Vol,3. No,2. Tahun 2019

e-ISSN: 2597-4440 dan p-ISSN: 2597-4424

This work is licensed under a Creative Commons Attribution

4.0 International License

\title{
Meningkatkan Aktivitas Berkomentar Melalui Media Pembelajaran Cerita Bergambar Pada Murid Tk Al-Ishaq Al-Patue Kabupaten Bone
}

\author{
Hamri \\ Dinas Pendidikan Kabupaten Bone \\ Email: hamri@gmail.com
}

\begin{abstract}
Abstrak. Penelitian ini bertujuan untuk meningkatkan: (1) Keaktifan belajar siswa, (2) pemahaman materi ajar, (3) kemandirian belajar berkomentar siswa, (4) meningkatkan hasil belajar siswa dan kemandirian siswa TK Al-Ishaq Al-Patue selama proses pembelajaran dengan media cerita bergambar. Subjek penerima tindakan adalah siswa kelompok A TK AlIshaq Al-Patue yang berjumlah 16 siswa, subjek pelaksana tindakan adalah peneliti dan subyek yang membantu pelaksana adalah guru TK Al-Ishaq Al-Patue dan kepala sekolah. Data dikumpulkan melalui observasi, catatan lapangan, review, dan dokumentasi. Analisis data secara deskriptif kualitatif dengan presentase dan model alur. Hasil penelitian tindakan kelas ini adalah pertama, kerja kolaboratif yang dikembangkan dapat meningkatkan pemahaman Guru TK Al-Ishaq Al-Patue, tentang, (1) masalah-masalah yang timbul di kelas, (2) cara-cara kerja kolaboratif menyusun suatu perencanaan perbaikan pembelajaran. Kedua, kerja kolaboratif berhasil melaksanakan perencanaan pembelajaran dengan baik, (1) bisa merubah kegiatan pembelajaran konvensional menjadi pembelajaran pendekatan belajar dengan melalui pemberian cerita bergambar, (2) bisa merubah kegiatan pembelajaran yang pasif menjadi pembelajaran aktif, kreatif dan interaktif, (3) pada setiap pembelajaran selalu memperhatikan aspek-aspek pembelajaran. Ketiga, dengan penerapan pembelajaran melalui pemberian pendekatan cerita bergambar terjadi peningkatan kemampuan berkomentar siswa yaitu ketuntasan pada siklus I $56.25 \%$, bahkan pada siklus II ketuntasan siswa sudah mencapai $87.50 \%$ yang artinya ada peningkatan yang cukup signifikan setelah diadakan model pembelajaran melalui pemberian media pembelajaran cerita bergambar.
\end{abstract}

Kata kunci: metode berkomentar, media cerita bergambar

\begin{abstract}
This study aims to improve: (1) Student learning activeness, (2) understanding teaching material, (3) students' independent learning independence, (4) improving student learning outcomes and the independence of TK Al-Ishaq Al-Patue students during the learning process with the media comic. The subjects of the action recipients were students of group A TK Al-Ishaq Al-Patue which amounted to 16 students, the subject of action was researchers and subjects who helped implementers were kindergarten teachers Al-Ishaq AlPatue and the principal. Data is collected through observation, field notes, reviews, and documentation. Qualitative descriptive data analysis with percentage and model flow. The results of this class action research are first, collaborative work developed can improve the understanding of Kindergarten Teacher Al-Ishaq Al-Patue, about, (1) problems that arise in the classroom, (2) ways of collaborative work to develop a learning improvement plan .
\end{abstract}


JIKAP PGSD: Jurnal Ilmiah Ilmu Kependidikan

Second, collaborative work successfully implements learning planning well, (1) can change conventional learning activities into learning approaches through the provision of the pictorial stories, (2) can change passive learning activities into active, creative and interactive learning, (3) on every learning always pays attention to aspects of learning. Third, with the application of learning through the presentation of the pictorial story approaches there was an increase in students 'commenting skills, namely completeness in cycle I $56.25 \%$, even in cycle II students' completeness had reached $87.50 \%$, which meant that there was a significant increase after learning models were given.

Keywords: method of commenting, pictorial story media

\section{PENDAHULUAN}

Sistem pendidikan dan pelaksanaan pembelajaran sering menjadi problema besar pada sektor pendidikan di Indonesia. Hal ini ditandai dengan adanya pembaharuan maupun eksperimen guna terus mencari kurikulum, sistem pendidikan, dan metode pengajaran yang efektif dan efisien. Berkomentar tentang pendidikan berarti berkomentar tentang manusia dengan segala aspeknya. Nilai suatu bangsa terletak dari kualitas sumber daya manusia yang menjadi warga Negara. Semakin baik kualitas manusianya, bangsa tersebut semakin memiliki peluang besar menuju kemajuan dan kemakmuran.

Pendidikan di Taman Kanak-Kanak (TK) merupakan pendidikan yang menyenangkan dengan prinsip "belajar sambil bermain, bermain seraya belajar". Berangkat dari sinilah pembelajaran yang ada di TK Al-Ishaq Al-Patue harus dicermati, sehinga apa yang diharapkan, yakni agar anak-anak lebih mandiri dalam segala hal sesuai dengan kapasitas anak bisa tercapai. Metode pengajaran yang tepat dan cermat akan mengarahkan anak-anak pada hasil yang optimal.

Macam-macam metode pengajaran di antaranya adalah metode berkomentar, permainan bahasa, sandiwara boneka, bercakap-cakap, dramatisasi, bermain peran, karya wisata, demontrasi, metode pemikiran dan perasaan terbuka, dan pemanasan atau apersepsi. Tiap-tiap metode tentu mempunyai tujuan secara khusus sekalipun kadang-kadang antara metode yang satu dengan metode yang lain mempunyai tujuan yang sama. Begitu juga dengan metode-metode yang lain, misalkan metode demontrasi, metode pemikiran dan perasaan terbuka, maupun metode pemanasan atau apersepsi masing-masing tentu mempunyai tujuan khusus.
Metode-metode tersebut adalah sebuah variasi atau pilihan dalam setiap melakukan kegiatan pembelajaran sesuai dengan tujuan yang diinginkan oleh setiap pengajar, sehingga tidak akan terjadi lagi penggunaan metode yang telah ditentukan melenceng atau tidak sesuia dengan tujuan yang diinginkan. Misalnya, penggunaan metode cerita yang dibantu dengan alat peraga yang menarik dan unik akan merangsang siswa untuk betul-betul memperhatikan setiap apa yang akan disampaikan oleh guru.

Untuk menjadikan agar anak mandiri, agar anak dapat melakukan sesuatu tanpa bantuan orang lain dan mampu mengungkapkan gagasan melalui komentar secara langsung adalah suatu harapan bagi semua pihak baik dari pihak sekolah maupun pihak orang tua atau wali murid, karena aktifitas berkomentar adalah suatu hal yang sangat penting yang harus dimiliki oleh setiap anak. Agar tidak selalu bergantung pada orang lain. Pada dasarnya, aktifitas berkomentar adalah hal atau keadaan dapat berdiri sendiri, tanpa bergantung pada orang lain. Oleh karena itu metode berkomentar dengan menggunakan alat peraga cerita bergambar adalah sebuah pilihan yang tepat.

\section{METODE PENELITIAN}

Jenis penelitian ini adalah penelitian tindakan kelas (Classroom Action Research). Pendekatan yang digunakan adalah pendekatan kualitatif yang berguna untuk mengungkapkan kesulitan belajar berkomentar siswa dalam mempelajari materi cerita bergambar, serta cara untuk mengatasi kesulitan-kesulitan tersebut sebagai upaya atau usaha dalam meningkatkan aktifitas berkomentar anak.

Penelitian ini dilaksanakan di TK Al-Ishaq Al-Patue Kabupaten Bone pada semester ganjil tahun pelajaran 2018/2019 dengan subjek 
penelitian siswa kelombok A TK Al-Ishaq AlPatue yang berjumlah 16 orang siswa. Adapun operasionalisasi variabel pada penelitian ini adalah:

1. Variabel bebas

Variabel bebas dalam penelitian ini adalah pengajaran dengan menggunakan media cerita bergambar.

2. Variabel terikat

Variabel terikat dalam penelitian ini adalah hasil belajar berkomentar siswa pada materi bidang pengembangan bahasa dengan cerita bergambar.

Penelitian ini terdiri dari dua siklus. Tiap siklus dilaksanakan sesuai dengan adanya perubahan yang ingin dicapai. Adapun langkahlangkah yang akan peneliti laksanakan yaitu:

1. Pembelajaran dilaksanakan dengan menggunakan media cerita bergambar. Khususnya membelajarkan cerita bergambar dimana guru bertindak sebagai pengajar, fasilitator, dan motivator.

2. Selama proses belajar mengajar berlangsung, peneliti dan teman sejawat bertindak sebagai observer/pengamat.

3. Observasi dilaksanakan pada saat pembelajaran berlangsung untuk melihat kelebihan dan kekurangan penggunaan media cerita bergambar.

4. Setelah proses belajar mengajar selesai dilaksanakan maka diadakan wawancara kepada siswa.

5. Untuk mengetahui ketuntasan belajar siswa, maka diadakan tes hasil belajar berkomentar siswa mengenai materi cerita bergambar.

Prosedur penelitian ini memiliki 4 tahapan.yaitu: (1) perencanaan, (2) pelaksanaan, (3) pengamatan, dan (4) refleksi (Arikunto, dkk: 2008).

Pengumpulan data penelitian ini dilaksanakan melalui tahapan tes, wawancara, dan observasi terhadap kelas yang menjadi sasaran penelitian. Adapun instrumen atau alat pengumpul data dalam penelitian yang digunakan dalam penelitian ini adalah tes berbentuk isian, wawancara, dan observasi aktivitas siswa serta observasi aktivitas guru selama kegiatan belajar mengajar berlangsung.

Analisis data penelitian ini dilakukan melalui tiga tahap yaitu reduksi data, paparan data dan penyimpulan data.

\section{Reduksi data}

Proses reduksi data dilakukan dengan menyeleksi, menyederhanakan, dan mentransformasikan data yang telah disajikan dalam transkrip catatan lapangan. Kegiatan reduksi data ini bertujuan untuk melihat kesalahan jawaban siswa dalam menyelesaikan soal-soal tentang cerita bergambar. dan tindakan apa yang dilakukan untuk perbaikan kesalahan tersebut.

2. Paparan data

Paparan data adalah proses penampilan data secara sederhana dalam tabel frekuensi ataupun grafik, dan sebagainya.

3. Penyimpulan data

Penyimpulan data adalah proses pengambilan intisari dari data yang sudah terorganisasikan tersebut dalam bentuk pernyataan kalimat atau formula yang singkat dan padat tetapi mengandung pengertian yang luas. Penarikan kesimpulan untuk mengetahui persentase kemampuan siswa sebagai hasil pengukuran ketuntasan kompetensi siswa yang telah ditetapkan oleh TK Al-Ishaq Al-Patue Kabupaten Bone digunakan rumus yaitu sebagai berikut:

Keterangan :

PPH $=$ Persentase Penilaian Hasil

$\mathrm{B}=$ Skor yang diperoleh

$\mathrm{N}=$ Skor total

Kriteria:

$0 \%<\mathrm{PPH}<65 \%$ Siswa belum tuntas belajar.

$65 \%<\mathrm{PPH}<100 \%$ Siswa sudah tuntas dalam belajar (Jadmiko: 2003).

Data yang dikumpulkan akan di analisis dengan menggunakan analisa kuantitatif dan kualitatif untuk analisa secara kuantitatif digunakan secara deskriptif yaitu dengan menggunakan skor rata-rata dan persentase, selain daripada itu akan ditentukan pula dengan standar deviasi, tabel frekfensi nilai terendah dan nilai tertinggi yang diperoleh siswa dari hasil evaluasi pada setiap akhir siklus I dan siklus II.

Pada analisis secara kualitatif akan digunakan teknik katagorisasi yang telah ditetapkan oleh Departemen Pendidikan Nasional (SNP. psl. 63 tentang standar penilaian) sebagai berikut:
1. Sangat baik
(A) $\quad=8,5-10$
2. Baik
(B) $\quad=7,0-8,4$
3. Cukup
(C) $\quad=5,5-6,9$
4. Kurang
(D) $\quad=4,0-5,4$
5. Kurang sekali
(E) $\quad=<4,0$ 
Adapun rumusan yang digunakan di dalam ketuntasan belajar adalah sebagai berikut:

1. Ketuntasan secara individu

Rumus persentase:

$\frac{\text { Jumlah skor yang diperoleh }}{\text { Jumlah skor maksimal }} \times 100 \%$

2. Ketuntasan secara klasikal

Rumus persentase ketuntasan :

$\frac{\text { Jumlah skor yang diperoleh }}{\text { Jumlah skor maksimal }} \times 100 \%$

Ketuntasan belajar individu dinyatakan tuntas apabila tingkat persentase ketuntasan minimal mencapai $65 \%$, sedangkan untuk tingkat klasikal minimal mencapai $85 \%$.

Indikator keberhasilan penelitian ini adalah apabila instrumen-instrumen yang telah disiapkan pada tiap-tiap siklus dapat dilaksanakan dengan baik, aktivitas siswa dalam belajar meningkat, lebih dari $85 \%$ siswa yang mendapat nilai $\geq$ bintang 3 .

\section{HASIL DAN PEMBAHASAN}

Berdasarkan hasil penilaian siswa terhadap tes awal berupa mengomentari cerita bergambar yang telah diberikan sebelum pelaksanaan tindakan, maka diperoleh data bahwa siswa kurang paham atau belum mampu mengomentari suatu cerita bergambar, sehingga hasil belajar berkomentar siswa rendah. Hal ini dapat dilihat pada presentase skor hasil belajar siswa, seperti tabel berikut ini:

Tabel. 4.2 Distribusi Frekuensi dan Persentase Skor Hasil Belajar pada pra siklus

\begin{tabular}{|c|c|c|c|}
\hline Skor & Kategori & Frekuensi & $\begin{array}{c}\text { Persentase } \\
(\%)\end{array}$ \\
\hline $0-34$ & Sangat & 4 & 25 \\
\hline $35-54$ & rendah & 7 & 43.75 \\
\hline 55- 64 & Rendah & 0 & 0 \\
\hline 65- 84 & Sedang & 5 & 31.25 \\
\hline 85- & Tinggi & 0 & 0 \\
\hline 100 & Sangat & & \\
\hline & Tinggi & & \\
\hline \multicolumn{2}{|c|}{ Jumlah } & 16 & 100 \\
\hline
\end{tabular}

Berdasarkan hasil tes awal yang dikategorikan masih rendah atau masih mengalami kesulitan maka selanjutnya dilakukan pembelajaran dengan kegiatan belajar sambil bermain dan disertai dengan demonstrasi. Setelah pembelajaran selesai maka dilakukan pos tes untuk mengetahui hasil belajar siswa.

Dari pos tes yang diberikan diperoleh bahwa masih ada beberapa siswa yang memiliki nilai dibawah 3. Nilai rata-rata pada saat pos tes I dari 16 siswa adalah 2.62. berikut tabel distribusi frekuensi dan presentase skor hasil belajar pada siklus I

Tabel. 4.4 Distribusi Frekuensi dan Persentase Skor Hasil Belajar pada siklus I

\begin{tabular}{c|c|c|c} 
Skor & Kategori & Frekuensi & $\begin{array}{c}\text { Persentase } \\
(\mathbf{\%})\end{array}$ \\
\hline $\mathbf{0 - 3 4}$ & Sangat & 1 & 6.25 \\
$\mathbf{3 5 - 5 4}$ & rendah & 6 & 37.5 \\
$\mathbf{5 5 - 6 4}$ & Rendah & 0 & 0 \\
$\mathbf{6 5 - 8 4}$ & Sedang & 7 & 43.75 \\
$\mathbf{8 5 -}$ & Tinggi & 2 & 12.5 \\
$\mathbf{1 0 0}$ & Sangat & & \\
& Tinggi & & 100
\end{tabular}

Untuk memperoleh hasil belajar yang lebih baik lagi, maka guru kelas kembali melaksanakan perbaikan pembelajaran pada siklus II. Dalam hal ini guru merasa perlu menambah tindakan-tindakan untuk memperbaiki hasil yang telah didapat pada siklus I, diantaranya proses belajar mengajar mengacu pada rencana pelajaran dengan memperhatikan revisi pada siklus I, sehingga kesalahan atau kekurangan pada siklus I tidak terulang lagi pada siklus II

Setelah dilakukan pembelajaran pada siklus II ternyata ada 8 orang siswa (50\%) yang memperoleh nilai maksimal bintang 4. Jika dilihat perolehan nilai rata-rata dari 16 siswa diperoleh 3.38. Hal ini menunjukkan adanya peningkatan hasil belajar siswa.

Tabel. 4.6 Distribusi Frekuensi dan Persentase Skor Hasil Belajar pada siklus II

\begin{tabular}{|c|c|c|c|}
\hline Skor & Kategori & Frekuensi & $\begin{array}{c}\text { Persentase } \\
(\%)\end{array}$ \\
\hline $0-34$ & Sangat & 0 & 0 \\
\hline $35-54$ & rendah & 2 & 12.5 \\
\hline 55- 64 & Rendah & 0 & 0 \\
\hline 65- 84 & Sedang & 6 & 37.5 \\
\hline 85- & Tinggi & 8 & 50 \\
\hline 100 & $\begin{array}{l}\text { Sangat } \\
\text { Tinggi }\end{array}$ & & \\
\hline \multicolumn{2}{|c|}{ Jumlah } & 14 & 100 \\
\hline
\end{tabular}


Berdasarkan tabel diatas dapat diketahui bahwa nilai rata-rata siswa pada saat diadakan tes awal adalah 2,06 dan siswa yang tuntas belajar adalah $31.25 \%$. Sedangkan saat pos tes pada siklus I dilaksanakan nilai rata-rata siswa meningkat menjadi 2.62 dan siswa yang tuntas belajar adalah $56.25 \%$. Kemudian pada pos tes siklus II nilai rata-rata siswa meningkat lagi menjadi 3.38 dan siswa yang tuntas belajar adalah $87.5 \%$. Dengan demikian, dapat dinyatakan bahwa kemampuan siswa meningkat dalam menguasai materi mengomentari cerita bergambar.

Ciri khas penelitian tindakan kelas adalah adanya siklus-siklus. Pada penelitian ini peneliti menjalankan dua siklus untuk mencapai hasil yang diinginkan.

\section{Siklus I}

a. Rencana (Planning)

Dalam penelitian ini kegiatan awal yang dilakukan peneliti adalah konsultasi dengan guru TK Al-Ishaq Al-Patue dan menyusun rencana pelaksanaan pembelajaran tentang cerita bergambar. Kemudian peneliti membuat lembar kerja siswa sebagai alat untuk mengumpulkan data tentang hasil belajar siswa.

b. Tindakan (Action)

Peneliti dan guru kelas TK melaksanakan tes awal untuk mengetahui pengetahuan awal siswa. Setelah itu pembelajaran dimulai dengan mengenalkan alat peraga yang digunakan dan peraturan dalam bermain dengan cerita bergambar (demonstrasi). Guru kelompok A TK Al-Ishaq AlPatue menyampaikan kepada siswa bahwa cerita bergambar yang akan dipelajari yaitu cerita bergambar yang bertema "kucing dan anjing". Setelah itu guru menjelaskan cerita bergambar melalui demonstrasi yang disertai alat peraga. Kemudian peneliti dan guru kelas memberikan lembar kerja siswa serta bahan-bahan untuk alat peraga kepada siswa yang telah dibagi dalam 5 kelompok. Guru berkeliling memantau dan membimbing siswa serta memberikan penjelasan bagi kelompok yang belum paham atau kelompok yang mengalami kesulitan.

c. Observasi (Obsevation)

Observasi dilaksanakan oleh peneliti sendiri pada saat proses pembelajaran berlangsung. Observasi dilakukan untuk melihat aktivitas siswa dalam menggunakan alat peraga dan demonstrasi pada cerita bergambar.

\section{d. Refleksi (Reflection)}

Pada akhir siklus diadakan refleksi terhadap hasil-hasil yang diperoleh peneliti melalui kegiatan bermain (demonstrasi) cerita bergambar dan selanjutnya dilakukan pos tes untuk mengetahui penguasaan siswa mengenai materi pokok cerita bergambar di kelompok A TK Al-Ishaq Al-Patue.

\section{Siklus II}

a. Rencana (Planning)

Perolehan nilai siswa yang diperoleh pada siklus I terdapat beberapa siswa yang memiliki nilai masih dibawah 65. Hal ini menunjukkan bahwa siswa masih kurang memahami atau kurang mampu mengomentari cerita bergambar. Dengan demikian peneliti dan guru TK kembali melakukan pembelajaran melalui siklus II dengan lebih memfokuskan pada penyelesaian tugas yang berhubungan dengan tes yang diberikan agar tercapai target yang diinginkan.

b. Tindakan (Action)

Pembelajaran dengan kegiatan bermain/ demonstrasi yang telah disusun oleh peneliti dan guru kelas diharapkan dapat meningkatkan hasil belajar siswa. Melalui kegiatan ini siswa lebih difokuskan untuk dapat menyelesaikan tugas yang telah diberikan.

\section{c. Observasi (Observation)}

Pada kegiatan belajar mengajar terlihat aktivitas siswa meningkat khususnya dalam mengomentari cerita bergambar.

\section{d. Refleksi (Reflection)}

Setelah pelaksanaan pembelajaran pada siklus II berakhir, peneliti dan guru kelas kembali melakukan pos tes I untuk mengetahui penguasaan siswa.

Setelah dilakukan pembelajaran pada siklus II dan pos tes II diperoleh peningkatan hasil belajar berkomentar siswa kelompok A TK AlIshaq Al-Patue pada cerita bergambar pada alur cerita melalui cerita bergambar. Dengan adanya peningkatan nilai rata-rata siswa dari pos tes I ke pos tes II, dan juga sekaligus menunjukkan bahwa tidak perlu lagi dilaksanakan perbaikan pembelajaran.

Untuk memperoleh gambaran yang jelas peningkatan hasil belajar siswa dari tes awal ke siklus I dan siklus II dapat dilihat pada gambar diagram berikut: 
1. Nilai Rata-rata:

\section{Nilai Rata-rata}

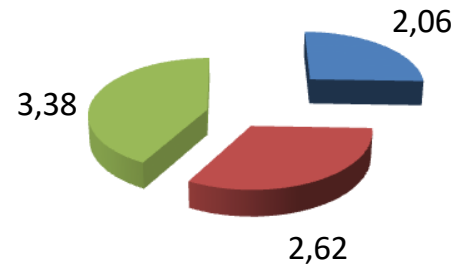

- Tes Awal

- Siklus I

Siklus II

2. Ketuntasan belajar:

Ketuntasan

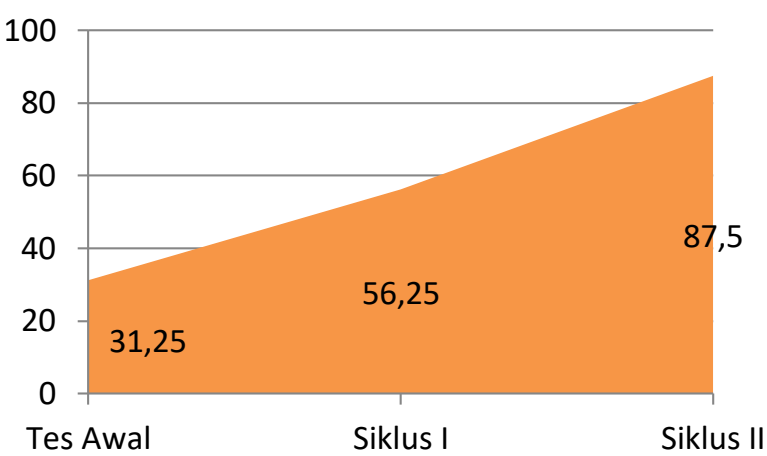

Berdasarkan dari tes awal, pos tes I dan pos tes II menunjukkan adanya peningkatan hasil belajar siswa. Nilai rata-rata siswa pada tes awal 2.06 dan ketuntasan $31.25 \%$, pos tes I sebesar 2.62 dan ketuntasan $56.25 \%$, dan pos tes II 3.38 dan ketuntasan belajar secara klasikal $87.5 \%$. Dengan demikian pembelajaran melalui media cerita bergambar dapat meningkatkan motivasi dan hasil belajar berkomentar siswa TK Al-Ishaq Al-Patue semester ganjil Tahun Pelajaran 2018/2019.

\section{SIMPULAN DAN SARAN}

Berdasarkan rumusan masalah, hasil analisis dan pembahasan, maka hasil penelitian ini dapat disimpulkan bahwa:

1. Pembelajaran dengan menggunakan media cerita bergambar dapat meningkatkan sifat aktifitas berkomentar dan hasil belajar siswa.

2. Dari hasil pelaksanaan siklus I diperoleh nilai rata-rata sebesar 2.62, dan tingkat ketuntasan belajar sebesar $56.25 \%$.

3. Dari hasil pelaksanaan siklus II diperoleh nilai rata-rata sebesar 3.38, dan tingkat ketuntasan belajar sebesar $87.50 \%$.
Berdasarkan kesimpulan yang dikemukakan diatas maka perlu dikemukakan saran sebagai berikut:

1. Bagi guru yang menerapkan pembelajaran dengan menggunakan media cerita bergambar hendaknya lebih teliti dalam penyajian, lebih sabar dan memperhatikan alokasi waktu yang ada.

2. Untuk membagi kelompok jangan hanya melihat dari nilainya saja, tetapi juga perhatikan kelakuan anak, sehingga bagi anak yang sering berulah tidak berada dalam satu kelompok.

3. Pada peneliti berikutnya, jika ingin melakukan jenis penelitian yang sama sebaiknya dilaksanakan lebih dari dua siklus, agar tecapai hasil yang lebih maksimal.

\section{DAFTAR RUJUKAN}

Ahmadi Abu, dkk. 2005. Strategi Belajar Mengajar. Bandung: Pustaka Setia

Agustina. 2006. Cerita bergambar. Semarang: Penerbit Andi.

Amin, Safwan. 2005. Pengantar Psikologi Pendidikan. Banda Aceh: Pena

Arikunto, dkk, 2008. Penelitian Tindakan Kelas. Jakarta: Bumi Aksara

Djamarah, S.B. dkk. 2006 Strategi Belajar Mengajar Jakarta: Rineka Cipta

Enco, Mulyoso. 2007. Menjadi Guru Profesional. Bandung: PT. Remaja Rosdakarya.

Gordon, Thomas. 1990. Guru Yang Efektif. Jakarta: PT Raja Grafindo Persada.

Jadmiko, B. 2003. Penelitian Tindakan Kelas (PTK). Jakarta: Depdikbud.

Lask, Bryan. 1991. Memahami dan Mengatasi Masalah Anak Anda. Jakarta: PT Gramedia Pustaka Utama.

Malik, Fadjar. 2003. Undang-undang Sistem Pendidikan Nasional. Jakarta: Sinar Grafika.

Paimin \& Ekaningsih Joula. 1998. Agar Anak Pintar. Manado: Puspa Swara.

Rochiati, Wiriaatmadja. 2007. Metode Penelitian Tindakan Kelas. Bandung: Rosda.

Sardiman. 2003. Interaksi \& Motivasi Belajar Mengajar, Jakarta: Raja Grafindo Persada

Sugianto, Mayke. 1995. Bermain, Mainan dan Permainan. Jakarta: Departemen pendidikan dan kebudayaan. 
Sujono. 1998. Pengajaran Cerita bergambar. Jakarta:

Susianti, D.Y. 2008. Pembelajaran Tematik Sebagai Upaya Meningkatkan Hasil Belajar siswa kelas 2 SDN 034 Samarinda Ulu.

Suryosubroto. 2002. Proses Belajar Mengajar di Sekolah, Jakarta: Rineka Cipta 